\title{
Analyzing the Effect of Risks on Adopting Internet Banking using SEM approach
}

\author{
Dr.J.DHILLIPAN, Dr.K.HARI, \\ Assistant Professor \& Head/MCA Dept, SRM University, Ramapuram Campus, Chennai. \\ Assistant Professor/Department of Business Administration, Sri Subramaniyaswamy Govt. Arts College, \\ Tiruttani.
}

\begin{abstract}
Internet banking has emerged as one of the most profitable E-commerce applications over the last decade. Although several prior research projects have focused on the factors that impact on the adoption of information technology or Internet, there is limited empirical work which simultaneously captures the risk factors that help customers to adopt online banking. The aforementioned factors cause complexity, challenge, ambiguity and risk feeling in the customers who use electronic capabilities. The main goal in this paper is to study the major risk factors that influencing the customer's intention to use of Internet Banking. Therefore, five groups of risk were identified as performance, security, time, social and financial categories. Based on an empirical study in the field of Internet Banking, the authors validated a measurement model used to explain customers' intention to use of Internet Banking, based on the above risk factors. The results indicated that all the risk factors are significant to the intention to use of Internet Banking. The knowledge of these risks as major factors of customer's adoption and perception in the internet provides banks as a useful tool for the establishment of an effective quality management for their e-businesses.
\end{abstract}

Keyword: Perceived Risk Model, Internet Banking, Risk Factors, Risks in adoption of online banking, SEM based risk model, Risk effects, Adoption of internet banking, Online banking adoption, issues in internet banking adoption and E-Security.

\section{Introduction}

Today the world has become smaller due to internet. The banking industry has started to use internet for their day to day operations. Still there are some users apprehensive about use of internet banking. Internet banking involves consumers using the Internet to access their bank account and to undertake banking transactions. At the basic level, internet banking can mean the setting up of a web page by a bank to give information about its products and services. At an advanced level, it involves provision of facilities such as accessing accounts, transferring funds, and buying financial products or services online. This is called "transactional" online banking (Sathye, 1999).Indian banks have a chequered history. The British legacy left behind a host of large and small privately-held banks. The late 1960s saw the nationalization of banks, leading to the emergence of the public sector banks. The 1990s saw the banking industry embracing technology in a massive way, led in particular by the new private banks and foreign banks. Among these series of technology innovations, Internet banking for the retail segment is a recent phenomenon that has generated a lot of interest in the Indian banking industry. Private and foreign banks have been the early adopters, while the PSU banks are the followers.

ICICI Bank kicked off online banking way back in 1996 and a host of other banks soon followed suit. After ICICI Bank, Citibank, Indus Ind Bank and HDFC Bank and Times Bank (now part of HDFC Bank), were the early ones to join the technology band wagon in 1999. While earlier research has focused on the factors influencing the end-user IT adoption, there is limited empirical work which simultaneously captures the success factors (positive) and resistance factors (negative) that drive customers to adopt Internet banking (Lee, 2009). Building upon the premise that purchasing Internet banking services is perceived to be riskier than purchasing traditional banking services (Cunningham, Gerlach, Harper, \& Young, 2005), this study introduces the perceived risk factor. Drawing from perceived risk theory, this study couples specific perceived risk facets (Featherman \& Pavlou, 2003) - namely performance, financial, time, social and time to explain customers' intention to adopt and use Internet banking. The main goal of this study, with regard to the use of this new issue of development in developing metropolitan areas, is to evaluate the impact of some key risks in adopting Internet Banking, particularly in Chennai.

\subsection{Literature Review}

Since the 1960s, perceived risk theory has been used to explain consumers' behavior. Considerable research has examined the impact of risk on traditional consumer decision making (Lin, 2008). 
Peter and Ryan (1976) defined perceived risk as a kind of subjective expected loss, and Featherman and Pavlou (2003) also defined perceived risk as the possible loss when pursuing a desired result.

Cunningham (1967) found that perceived risk consisted of the size of the potential loss (i.e. that which is at stake) if the results of the act were not favorable and the individual's subjective feelings of certainty that the results will not be favorable.

Most of scholars claimed that consumers' perceived risk is a kind of a multi-dimensional construct. Six components or types of perceived risk have been identified: financial, performance, social, physical, privacy, and time-loss (Jacoby and Kaplan, 1972; Kaplan et al., 1974; Roselius, 1971).

However, the dimensions of perceived risk may vary according to the product (or service) class Featherman and Pavlou, 2003. Internet does not incur any threat to human life; therefore, measures of physical risk were not included in this study. We define perceived risk factors that influencing the intention to use of internet banking in public and private sector banks in Chennai.

\subsubsection{Perceived Risks Of Internet Banking}

The present research investigated five types of risk - security/ privacy, financial, social, ime/convenience, and performance loss, and the details of these five risks related to online banking are described as follows:

1. Security/privacy risk: This is defined as a potential loss due to fraud or a hacker compromising the security of an online bank user. Phishing is a new crime skill by which phishers attempt to fraudulently acquire sensitive information, such as usernames, passwords and credit card details, by masquerading as a trust worthy entity in an electronic communication (Reavley, 2005). A phising attack takes places when a user receives a fraudulent email (often referred to as a spoof email) representing a trusted source that leads them to an equally fraudulent website that is used to collect personal information (Entrust, 2008). Both fraud and hacker intrusion not only lead to users' monetary loss, but also violate users' privacy, a major concern of many Internet users. Many consumers believe that they are vulnerable to identity theft while using online banking services (Littler and Melanthiou, 2006).

2. Financial risk: It is defined as the potential for monetary loss due to transaction error or bank account misuse. According to Kuisma et al. (2007), many customers are afraid of losing money while performing transactions or transferring money over the Internet. At present online banking transactions lack the assurance provided in traditional setting through formal proceedings and receipts. Thus, consumers Usually have difficulties in asking for compensation when transaction errors occur (Kuisma et al., 2007).

3. Social risk: This refers to the possibility that using online banking may result in disapproval of one's friends/family/work group. It is possible that one's social standing may be enhanced or diminished depending on how online banking is viewed. It may well be that people have unfavorable or favorable perceptions of online banking that in turn affect their views of its adopters; or, alternatively, not adopting online banking may also have negative or positive connotations.

4. Time/convenience risk: It may refer to the loss of the time and inconvenience incurred due to the delays of receiving the payment or the difficulty of navigation (finding appropriate services and hyperlinks). Two leading causes of dissatisfying online experiences that may be thought of as a time/convenience risk include a disorganized or confusing Web site and pages that are too slow to download (Forsythe and Shi, 2003). It may also be related to the length of time involved in waiting the website or learning how to operate online banking website.

5. Performance risk: This refers to losses incurred by deficiencies or malfunctions of online banking websites. Customers are often apprehensive that a breakdown of system servers or disconnection from the Internet will occur while conducting online transactions because these situations may result in unexpected losses (Kuisma et al., 2007).

\subsection{Objectives Of The Study}

The objectives of the study are as follows,

1. To identify the risk factors that influencing the adoption of internet banking in the Public and Private Sector Banks in Chennai, and

2. To develop a Structural Equation Model (SEM) for the study.

\subsection{Research Model And Hypothesis Deveopment}

\section{4 a) Research Model:}

There are six constructs in our model which includes performance risk, financial risk, social risk, time risk, security risk and adoption. We will test the strength of the hypothesized relationships embedded in the theoretical model using PLS 2.3 and the robustness of the model in predicting that how risk factors have significant effect on adoption of internet banking in public and private sector banks in our study area. 


\section{Structural Model}

The six constructs of the study are conceptually related to each other by the structural model as shown in the figure: 1

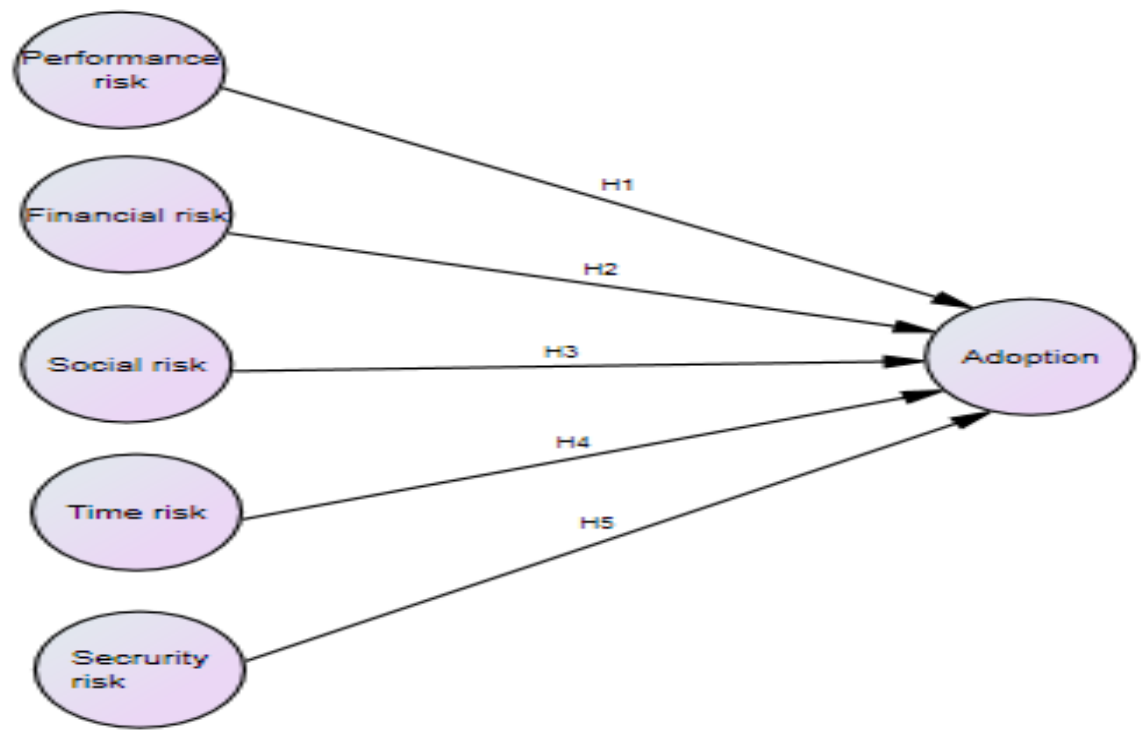

Fig. 1 Theoretical Model

A PLS model is analyzed and interpreted in two stages: 1) The assessment of the reliability and validity of the measurement model and 2) The assessment of the structural model. This sequence ensures that the constructs' measures are valid and reliable before attempting to draw conclusions regarding relationships among constructs. Structural model specifies relations between latent constructs. Estimating and analyzing the path coefficients between the constructs test the structural model. Path coefficients are indicators of the model's predictive ability.

\section{4 b) Hypothesis Development}

Based on the theoretical model developed in Fig.1, we formulated the following research hypotheses. As TAM is used as the base models, we need to test the following hypotheses in the context of internet banking adoption.

H1: Performance Risk has significant influence on adoption of internet banking.

H2: Financial Risk has significant influence on adoption of internet banking.

H3: Social Risk has significant influence on adoption of internet banking.

H4: Time Risk has significant influence on adoption of internet banking.

H5: Security Risk has significant influence on adoption of internet banking.

\subsection{Research Methodology}

\section{5 a) Data collection}

Structured Questionnaire has been used to collect the primary data from the customers of banks like State bank of India, Indian Overseas Bank, ICICI Bank and HDFC Bank in Chennai. It has three parts: Part I consists of Demographic Profile of the study bank customers, Part II consists of Banking Services details and Part III consists of six constructs that are hypothesized to influence the adoption of internet banking.

The target questions focus on the five independent constructs such as performance risk, financial risk, social risk, time risk, security risk and one dependent constructs, actual use. The scaling used in this study is the 5point Likert scale of 1-strongly disagree, 2-disagree, 3-neutral, 4-agree and 5-strongly agree.

\section{5 b) Sample size}

The sample was taken from two public sector banks and two private sector banks in Chennai. The public sector banks are State Bank of India and Indian Overseas of Bank and the private sector banks are ICICI bank and HDFC bank. These banks are selected based on excellent performance in providing internet banking services (Vizisense report, April $19^{\text {th }} \& 21^{\text {st }}, 2011$ and Financial \& Market News, Indian News) and comprising huge number of internet banking users in Chennai.

Table 1 shows the sample size of the study, 
Table 1

\begin{tabular}{|l|l|}
\hline Name of the bank & No. of Customers from each bank \\
\hline State Bank of India & $\mathbf{3 5 0}$ \\
\hline Indian Overseas Bank & $\mathbf{3 0 0}$ \\
\hline ICICI Bank & $\mathbf{2 5 0}$ \\
\hline HDFC Bank & $\mathbf{2 0 0}$ \\
\hline Total & $\mathbf{1 1 0 0}$ \\
\hline
\end{tabular}

One thousand and two hundred and fifty (1250) questionnaires are distributed to the respondents who returned 1185 of the questionnaires while seventy five (65) questionnaires were unreturned. Another 85 questionnaires were incomplete leaving one thousand and one hundred (1100) questionnaires for further analysis or $88 \%$ response rate.

\section{5 c) Data Screening and Analysis}

The data were input into SPSS version 20 software program and analyzed using PLS version 2.3. Several statistical validity tests and analysis were conducted such as reliability test and composite reliability tests, validity tests using SEM analysis for construct validity, discriminant validity for descriptive analysis and structural equation modeling analysis using PLS version 2.3.

\subsection{Research Findings}

\section{6 a) Measurement Model}

The measurement model for reflective constructs is assessed in terms of Individual item reliability, Construct reliability, and Convergent validity and Discriminant validity. Initially the relationships were displayed between the constructs of analysis factor and reference factor with investment choice which has the relationship with riskless factors and return factor and both have the relationship with customer satisfaction. PLS algorithm was applied and the resultant relationship, coefficients and values of loadings are shown in figure 2. In PLS, loadings of respective factors on their respective latent constructs are examined to assess the reliability of the factors. Since the final model was decided after dropping out insignificant factors having factor loadings of less than 0.5

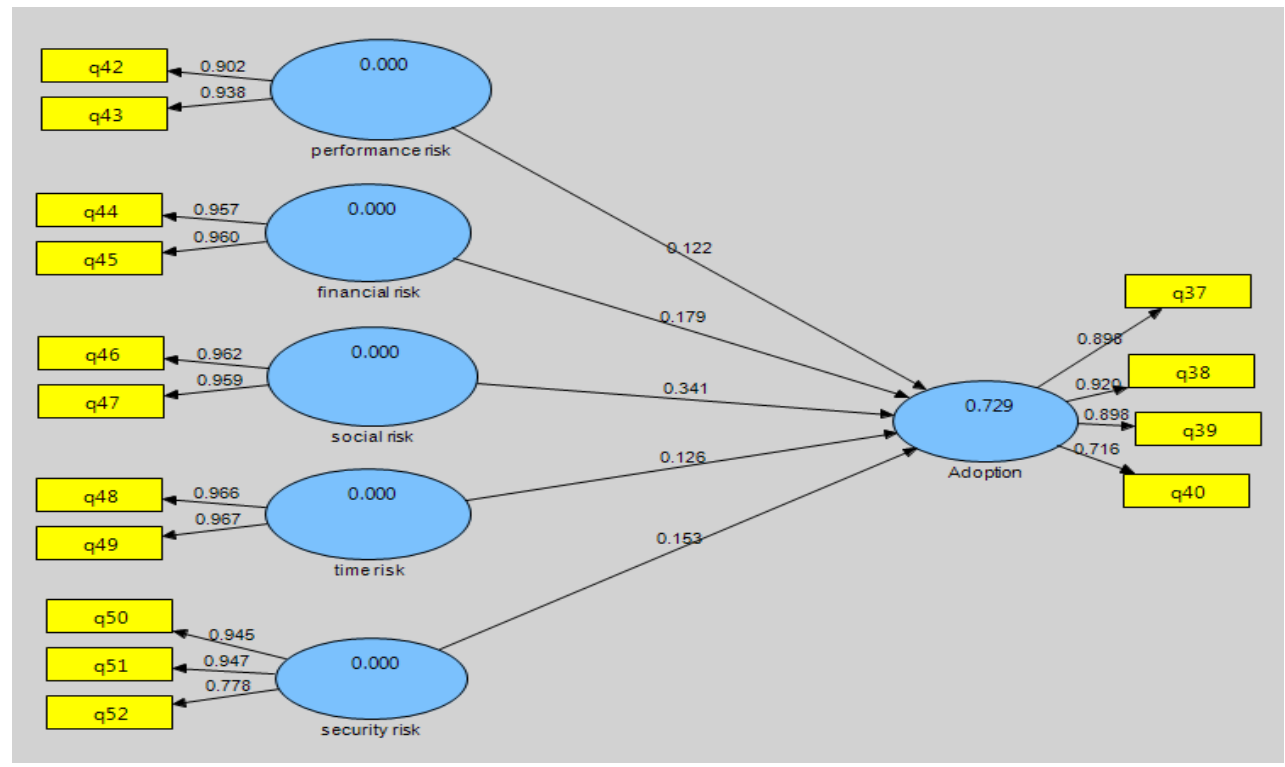

Figure 2 Final Path Model

\section{6 b) Validity and Reliability:}

Reliability: Referring to table 2, for factor loadings, the cut-off criterion of 0.5 was considered as a strong factor loading coefficient (Hair et.al 2010; Hulland 1999). In addition to Cronbach's alpha, reliability of each variable was assessed through Fornell and Larcker's measures of composite reliability. This measure is preferred over Cronbach's alpha because it offers a better estimate of variance shared by the respective indicators and because it offers a better estimate of variance shared by the respective indicators and because it uses the item loadings obtained within the homological network (Hair et.al, 2006). In this study the composite reliability values construct range from 0.91 to 0.96 which is exceeded the standard value of 0.70 (Fornell and Larcker, 1981; Hair, Anderson \& Black, 1998). The factor loadings, Cronbach's alpha, Composite reliability and Average Variance Extracted (AVE) values calculated by PLS algorithms are tabulated in table 2. 
Table 2: Factor loadings, Cronbach's alpha, Composite reliability and AVE values

\begin{tabular}{|c|c|c|c|c|}
\hline Constructs & Factor loadings & $\begin{array}{l}\text { Cronbach's } \\
\text { alpha }\end{array}$ & $\begin{array}{l}\text { Composite } \\
\text { reliability }\end{array}$ & Average variance Extracted \\
\hline \multicolumn{2}{|c|}{ Performance Risk } & 0.8217 & 0.9173 & 0.8472 \\
\hline$q 42$ & 0.9022 & & & \\
\hline $\mathrm{q} 43$ & 0.9383 & & & \\
\hline \multicolumn{2}{|c|}{ Financial Risk } & 0.9109 & 0.9573 & 0.9181 \\
\hline$q 44$ & 0.9565 & & & \\
\hline$q 45$ & 0.9599 & & & \\
\hline \multicolumn{2}{|l|}{ Social Risk } & 0.9156 & 0.9595 & 0.9221 \\
\hline $\mathrm{q} 46$ & 0.9618 & & & \\
\hline q47 & 0.9588 & & & \\
\hline \multicolumn{2}{|l|}{ Time Risk } & 0.9299 & 0.9662 & 0.9345 \\
\hline $\mathrm{q} 48$ & 0.9661 & & & \\
\hline$q 49$ & 0.9673 & & & \\
\hline \multicolumn{2}{|c|}{ Security Risk } & 0.8721 & 0.9219 & 0.7987 \\
\hline $\mathrm{q} 50$ & 0.9454 & & & \\
\hline $\mathrm{q} 51$ & 0.9474 & & & \\
\hline $\mathrm{q} 52$ & 0.7777 & & & \\
\hline \multicolumn{2}{|l|}{ Adoption } & 0.8822 & 0.9198 & 0.7432 \\
\hline q37 & 0.8981 & & & \\
\hline $\mathrm{q} 38$ & 0.9202 & & & \\
\hline q39 & 0.8983 & & & \\
\hline $\mathrm{q} 40$ & 0.7159 & & & \\
\hline
\end{tabular}

Convergent validity: The evidence of convergent validity was assessed to examine the variance extracted for each factor. The AVE also exceeded the recommended value of 0.50 (Fornell and Larcker, 1981; Barclay et at. 1995; Hair, Anderson \& Black, 1998) which range from 0.74 to 0.93 and results indicated that variance extracted from the constructs possessed convergent validity.

Discriminant validity: Discriminant validity is the extent to which any single construct is different from the other constructs in the model (Carmines and Zeller, 1979; Cheung \& Lee 2010). Discriminant validity was assessed by measuring the pair-wise correlations between factors obtained were compared with the variance extracted estimates for the constructs making up each possible pair. To assess the discriminant validity AVE should be greater than the variance shared between the construct and other constructs in the model (Chin, 1998). In addition, discriminate validity is confirmed if the diagonal elements are significantly higher than the offdiagonal values in the corresponding rows and columns. The diagonal elements are the square root of the AVE score for each construct.(Teo, 2009; Roldan \& Sanchez - Franco, 2012). These values are shown in table 3. Result revealed that all the constructs possess Discriminant validity

Table 3: Showing the Discriminant Validity Results

\begin{tabular}{|l|l|l|l|l|l|l|}
\hline Constructs & $\begin{array}{l}\text { Financial } \\
\text { risk }\end{array}$ & Adoption & $\begin{array}{l}\text { Performance } \\
\text { risk }\end{array}$ & Security risk & $\begin{array}{l}\text { Social } \\
\text { risk }\end{array}$ & Time risk \\
\hline Financial risk & $\mathbf{0 . 9 5 8 2}$ & & & & & \\
\hline Adoption & 0.7951 & $\mathbf{0 . 8 6 2 1}$ & & & & \\
\hline Performance risk & 0.8234 & 0.7247 & $\mathbf{0 . 9 2 0 4}$ & & & \\
\hline Security risk & 0.8005 & 0.7656 & 0.7023 & $\mathbf{0 . 8 9 3 7}$ & & \\
\hline Social risk & 0.848 & 0.8196 & 0.7355 & 0.8114 & $\mathbf{0 . 9 6 0 3}$ & \\
\hline Time risk & 0.8167 & 0.7978 & 0.762 & 0.8417 & 0.8882 & $\mathbf{0 . 9 6 6 7}$ \\
\hline
\end{tabular}

From table 3 , the measurement demonstrates that there is adequate discriminant validity, since the diagonal elements are significantly greater than the off-diagonal elements in the corresponding rows and columns. In total, the measurement model has demonstrated adequate convergent validity and discriminant validity.

\section{6 c) Structural Model Analysis}

In PLS method, structural model and hypothesis were tested by computing path coefficients ( $\beta$ ). PLS provides to determine how well the model fits the hypothesized relationship is the squared multiple correlations $\left(\mathrm{R}^{2}\right)$ for each dependent construct in the model. $\mathrm{R}^{2}$ values of the dependent constructs indicate whether a particular PLS model accomplishes the objective of maximizing the variance explained (Chin, 1998). The bootstrapping technique was used (using 1000 sub samples) to evaluate the statistical significance of each path coefficient. The t-values of the parameter indicate the strength of the relationship in the parameter represents; therefore the higher the t-value, the stronger the relationship (Huang, Lin \& Chuang, 2007) 
Table 4: Showing the path coefficients along with their ' $T$ ' values

\begin{tabular}{|l|l|l|l|l|l|l|l|l|}
\hline H & Constructs & $\begin{array}{l}\text { Original } \\
\text { Sample } \\
(\mathbf{O})\end{array}$ & $\begin{array}{l}\text { Sample } \\
\text { Mean } \\
(\mathbf{M})\end{array}$ & $\begin{array}{l}\text { Standard } \\
\text { Deviation }\end{array}$ & $\begin{array}{l}\text { Standard } \\
\text { Error }\end{array}$ & $\begin{array}{l}\text { T Statistics } \\
(\mid \mathbf{O} / \text { SE })\end{array}$ & $\begin{array}{l}\text { Path } \\
\text { coefficient } \\
(\boldsymbol{\beta})\end{array}$ & $\begin{array}{l}\text { Result } \\
0.1224\end{array}$ \\
\hline H1 & $\begin{array}{l}\text { Performance risk -> } \\
\text { Adoption }\end{array}$ & 0.1224 & 0.1231 & 0.0474 & 0.0474 & $2.5909^{* *}$ & Supported \\
\hline H2 & $\begin{array}{l}\text { Financial risk -> } \\
\text { Adoption }\end{array}$ & 0.1795 & 0.1786 & 0.0407 & 0.0407 & $4.4056^{* * *}$ & 0.1795 & Supported \\
\hline H3 & $\begin{array}{l}\text { Social risk -> } \\
\text { Adoption }\end{array}$ & 0.341 & 0.3419 & 0.0337 & 0.0337 & $10.126^{* * *}$ & 0.341 & Supported \\
\hline H4 & $\begin{array}{l}\text { Time risk -> } \\
\text { Adoption }\end{array}$ & 0.1265 & 0.1259 & 0.0382 & 0.0382 & $3.3108^{* * *}$ & 0.1265 & Supported \\
\hline H5 & $\begin{array}{l}\text { Security risk -> } \\
\text { Adoption }\end{array}$ & 0.1529 & 0.1525 & 0.0321 & 0.0321 & $4.7623^{* * *}$ & 0.1529 & Supported \\
\hline
\end{tabular}

Note: $* * * \mathrm{p}<0.01$ at $\mathrm{t}-\mathrm{value}=2.58, * * \mathrm{p}<0.05$ at $\mathrm{t}-$ value $=1.96$

The results in table 4 indicated that social risk $(\beta=0.341, \mathrm{p}<0.01)$, Security risk $(\beta=0.1529, \mathrm{p}<0.01)$, Financial risk $(\beta=0.1795, \mathrm{p}<0.01)$, Time risk $(\beta=0.1265 \mathrm{p}<0.01)$ and Performance risk $(\beta=0.1224, \mathrm{p}<0.05)$ have an significant influence on adoption of internet banking and support the hypothesis which explaining $73 \%$ $\left(\mathrm{R}^{2}\right)$ of variance present in adoption of internet banking.

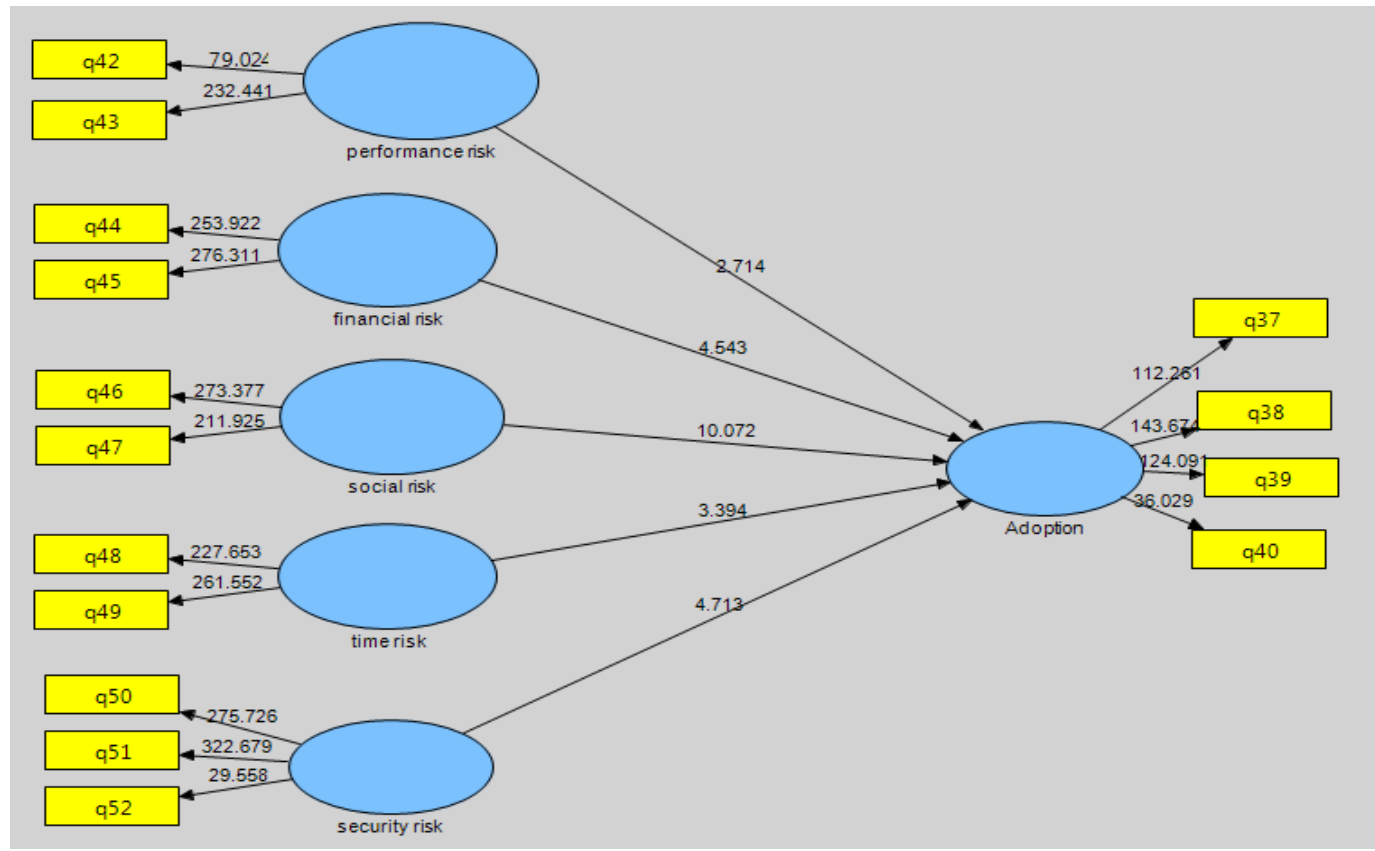

Figure 3: Bootstrapping Technique

\section{6 d) Model Evaluation}

Structural model is mainly evaluated by Goodness-of-fit (Gof) and by using Stone-Geiser $\mathrm{Q}^{2}$ test for predictive relevance. Goodness-of-fit (GoF) was used to measure the overall fit of the model. For this model the GoF index was 0.7919 (see table 5). Further the quality of path model can also be evaluated by cross -validated redundancy index $\left(\mathrm{Q}^{2}\right)$ for the endogenous variable. $\mathrm{A} \mathrm{Q}^{2}$ greater than zero implies that the structural model has satisfactory predictive relevance for the model (Roldan \& Sanchez - Franco, 2012). In PLS two kinds of $Q^{2}$ statistics are estimated by using Blind fold method of calculations. They are cross-validated communality $\left(\mathrm{H}^{2}\right)$ and cross-validated redundancy $\left(\mathrm{F}^{2}\right)$. The results are shown in table 5 and figure 4

Table 5: Showing Model Evaluation results

\begin{tabular}{|l|l|l|l|l|l|}
\hline Constructs & $\mathrm{R}^{2}$ & Communality & $\mathrm{H}^{2}$ & Redundancy & $\mathrm{F}^{2}$ \\
\hline Financial risk & - & 0.9181 & 0.6108 & - & - \\
\hline Adoption & 0.7288 & 0.7432 & 0.5726 & 0.1874 & 0.5267 \\
\hline Performance risk & - & 0.8472 & 0.4585 & - & - \\
\hline Security risk & - & 0.7987 & 0.582 & - & - \\
\hline Social risk & - & 0.9221 & 0.6199 & - & - \\
\hline Time risk & - & 0.9345 & 0.6476 & - & - \\
\hline Average & 0.7288 & & & \\
\hline GoF $=\sqrt{\text { average } \mathrm{R}^{2} \mathrm{x} \text { average communality }=\sqrt{0.6272=0.7919}}$ \\
\hline
\end{tabular}


It is observed from the table 5 that for this model all the constructs had values of $\mathrm{H}^{2}$ and $\mathrm{F}^{2}$ were positive; hence the model had acceptable relevance.

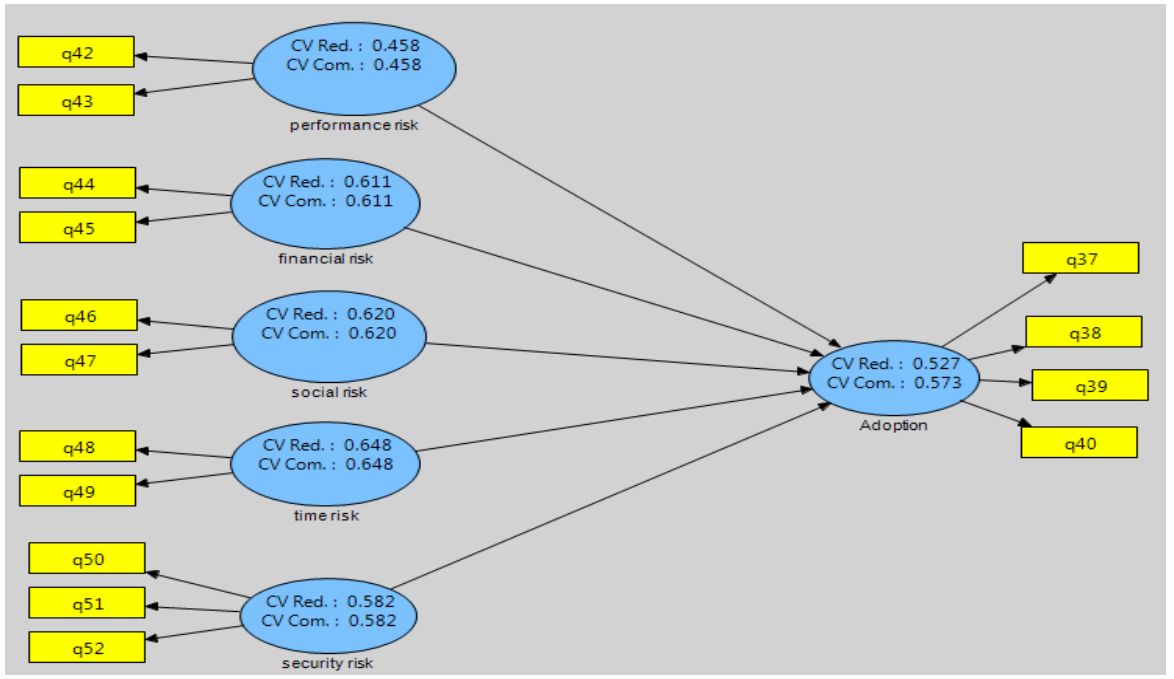

Figure 4: Blind Folding Path Modeling

\subsection{Conclusion and Implication}

The results of this study provide support for the research model presented in Fig. 1 and for the hypotheses regarding the directional linkage among the model's variables. The results in table 4 indicated that social risk $(\beta=0.341, p<0.01)$, Security risk $(\beta=0.1529, p<0.01)$, Financial risk $(\beta=0.1795, p<0.01)$, Time risk $(\beta=0.1265 \mathrm{p}<0.01)$ and Performance risk $(\beta=0.1224, \mathrm{p}<0.05)$ have an significant influence on adoption of internet banking and support the hypothesis which explaining $73 \%\left(\mathrm{R}^{2}\right)$ of variance present in adoption of internet banking. The results of this study shed light on some important issues related to risk factors towards the adoption of internet banking that have not been addressed by previous studies. First, although all the risk factors have significant influence on adoption of internet banking in the study area and this study reveals that social risk is a more influential factor compared to other factor and also implying that controlling the risk of internet banking is more important than providing benefits. This finding is particularly important for bank managers as they decide how to allocate resources to retain and expand their current customer base. However, building a risk-free online transaction environment is much more difficult than providing benefits to customers. Therefore, banks need to search for risk-reducing strategies that might assist in inspiring high confidence in potential customers. This study suggests that they should consider focusing on the prevention of intrusion, fraud and identity theft.

Second, this paper aims to develop a SEM model to predict and explain risk factors have significant influence with regard to adopting internet banking. The proposed model incorporates five categories of perceived risk to provide a more comprehensive investigation covering the aspects of internet banking. The results show that the proposed model has good explanatory power and confirms its robustness in predicting customers' adoptions to use such services. Finally, it is proposed to add new variables to the model of the study or use it in other different banks. Such practice makes it possible to compare results with the results of current study. Banks can use these results in their policy making in order to increase the possibility of their succession.

\section{References}

[1]. Barclay, D., Higgins, C., \& Thompson, R. (1995), "The partial least squares (PLS) approach to causal modelling: Personal computer adoption and use as an illustration", Technology Studies, 2, pp 285-309.

[2]. Carmines, E. G., \& Zeller, R. A. (1979), "Reliability and validity assessment. In Sage University Paper series on quantitative applications in the social sciences. N. 07-017.Beverly Hills: Sage.

[3]. Cheung, C. M. K., \& Lee, M. K. O. (2010), "A theoretical model of intentional social action in online social networks", Decision Support Systems, 49(1), pp 24-30.

[4]. Chin, W. W. (1998), "The partial least squares approach for structural equation modeling. In George A., \& Marcoulides (Eds.), Modern Methods for Business Research, Lawrence Erlbaum Associates pp. 295-336.

[5]. Cunningham SM. The major dimensions of perceived risk. In: Cox DF, editor. Risk taking and information handling in consumer behaviour. Boston: Harvard University Press; 1967.

[6]. Cunningham, L.F., J. Gerlach and M.D. Harper, 2005. Perceived risk and e-banking services: An analysis from the perspective of the consumer. J. Finance Services Market., 10: 165-178. DOI: 10.1057/palgrave.fsm.4770183.

[7]. Entrust, 2008. Pshing attack. Available from: <http://www.entrust.com/phishing/ index.htm>

[8]. Featherman, M. S., \& Pavlou, P. A. (2003). Predicting e-services adoption: a perceived risk facets perspective. International Journal of Human-Computer Studies, 59(4), 451-474. 


\section{Analyzing the Effect of Risks on Adopting Internet Banking using SEM approach}

[9]. Fornell, C., \& Larcker, D. F. (1981), "Evaluating structural equation models with unobservable variables and measurement error",Journal of Marketing Research, 18, pp 39-50.

[10]. Forsythe SM, Shi B. Consumer patronage and risk perceptions in internet shopping. J Bus Res 2003;56:867-75.

[11]. Hair, J. E., Anderson, R. E., Tatham, R. L., \& Black, W. C. (1998), "Multivariate data analysis", 5th ed., Prentice-Hall, Upper Saddle River, NJ

[12]. Hair, J. F., Black, W. C., Babin, B. J., \& Anderson, R. E. (2010), "Multivariate data analysis": Prentice-Hall, Upper Saddle River, NJ

[13]. Huang, J., Lin, Y., \& Chuang, S. (2007), "Elucidating user behaviour of mobile learning: A perspective of the extended technology acceptance model", The Electronic Library, 25(5),

[14]. Hulland, J. S. (1999), "Use of partial leasts quares (PLS) in strategic management research: A review of four recent studies", Strategic Management Journal, 20(4), pp 195-204.

[15]. Jacoby J, Kaplan L. B the components of perceived risk. In: Venkatesan M, editor. Advances in consumer research. Chicago: Association for Consumer Research, 1972.

[16]. Kaplan LB, Szybille GJ, et al. Components of perceived risk in product purchase: a cross validation. J Appl Psychol 1974;59(3):278-91.

[17]. Kuisma T, Laukkanen T, Hiltunen M. Mapping the reasons for resistance to internet banking: a means-end approach. Int J Inform Manage 2007;27(2):75-85.

[18]. Peter JP, Ryan MJ. An investigation of perceived risk at the brand level. J Market Res 1976;13: 184-8.

[19]. Reavley N. Securing online banking. Card Technol Today 2005;17(10):12-3.

[20]. Roldán, J. L., \& Sánchez-Franco, M. J. (2012). "Variance-based structural equation modeling: Guidelines for using partial least squares in information systems research". Information Science Reference. pp 193-221.

[21]. Roselius T. Consumer rankings of risk reduction methods. J Market 1971;35(1):56-61.

[22]. Sathye, M. (1999), Adoption of internet banking by Australian consumers: an empirical investigation, International Journal of Bank Marketing, 17 (7), 324-34.

[23]. Teo, T. (2009). Examining the relationship between student teachers' self-efficacy beliefs and their intended uses of technology for teaching: A structural equation modelling approach. The Turkish Online Journal of Educational Technology, 8(4), pp 7-16.

[24]. Lee, M.C., 2009. Factors influencing the adoption of internet banking: An integration of TAM and TPB with perceived risk and perceived benefit. Electron. Commerce Res. Applic., 8: 130-141. DOI: 10.1016/j.elerap.2008.11.006.

[25]. Lin W-B. Investigation on the model of consumers' perceived risk - integrated viewpoint. Expert Syst Appl 2008; 34(1):977-88.

[26]. Littler D, Melanthiou D. Consumer perceptions of risk and uncertainty and the implications for behaviour towards innovative retail services: the case of internet banking. J Retailing Consum Serv 2006;13(6):431-43. 